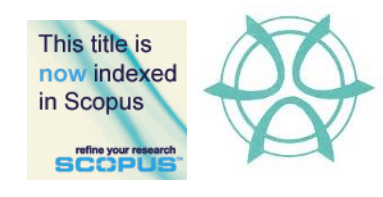

PLANNING MALAYSIA:

Journal of the Malaysian Institute of Planners

VOLUME 16 ISSUE 2 (2018), Page 217 - 224

\title{
A STUDY OF CONSTRUCTION WASTE PRACTICE IN SELANGOR
}

\author{
Khor Soo Cheen ${ }^{1}$, Lim Chin-Yieh ${ }^{2}$, Tan Seong Yeow ${ }^{3}$, Olanrewaju \\ Adullateef Ashola ${ }^{4}$, Nik Nurul-Hidayah Nik Yahya ${ }^{5}$, Wai Soon Han ${ }^{6}, \&$ \\ Mohaad Nizam Yusof ${ }^{7}$
}

1,2,3,4,5,6 Faculty of Engineering and Green Technology, UNIVERSITI TUNKU ABDUL RAHMAN MALAYSIA

${ }^{7}$ School of Housing, Building and Planning UNIVERSITI SAINS MALAYSIA

\begin{abstract}
The development of construction sector has produced mass volume of construction waste. The aim of this research is to give background information on the construction waste problem in Selangor and to acknowledge the practical method of management in order to reduce construction waste. The quantification of construction waste is used to measure the waste index of the construction project in Selangor. A survey is conducted in order to collect the data needed in quantification of construction waste. The data is used to calculate the project waste indexes for construction projects. The amount of waste can therefore be detected explicitly to alert the construction stakeholders for undertaking preventive measures to reduce the waste production. The approaches adopted for construction waste reduction are stated in this research. The findings revealed that the studied companies practiced good management methods for construction waste. The results were prominent when compared with the benchmarked waste index of construction projects and demolition in Hong Kong.
\end{abstract}

Keywords: construction waste, quantification, waste index, waste reduction, Selangor. 
Khor Soo Cheen, Lim Chin-Yieh, Tan Seong Yeow, Olanrewaju A.A, Nik Nurul-Hidayah N.Y Wai Soon Han, \& Mohaad N.Y

A Study of Construction Waste Practice in Selangor

\section{INTRODUCTION}

The development of construction industry unfortunately generates plenty of byproducts of construction waste. Construction waste is substance produced from demolition, excavation, renovation, refurbishment, road work and site clearance (HK EPD, 2015; Hashim, Rabe, Osman, \& Zahari, 2017). However, the management of construction waste can be sorted for reuse, recycle and disposal for the purpose of environmental conservation. Besides that the type and amount of construction waste depend on the size of projects such as low rise project or high-rise project, construction technology deployment and the activities performed in the project (Masudi, Che Hassan, Mahnood, Mokhtar, \& Sulaiman, 2011).

Extra estimation of material usually happens in pre-construction stage because of insufficient concern on waste generated in the planning stage and design stage. The extra estimation of the material use will cause the employer to pay more in material cost but decrease the contractor's profit margin ("Estimating Errors \& Cost Overruns", 2016). The severe effect is the impact of construction waste illegal disposal to the environmental problem that might cause the adverse health problem to this society (Mohd Din, Nik Yahya, \& Abdullah 2013).

One of the factors that cause inefficiency of managing the construction waste is lack well recycling markets. The waste management is inefficient and ineffective without a good recycling market (Tey, Goh, Kek, \& Goh, 2016). This problem has to be solved by effective and systematic waste management planning to minimize environmental problems. To do so, the information such as waste generated amount, content of waste generated and types of method use to handle the construction waste have to be identified.

Additionally, the action of dumping the construction waste at landfill has cause major environmental problem. The amount of 7,375 tonnes of trash is being produced every day along with the disposal of construction waste. Selangor landfills have a short lifespan and the state is running out of suitable sites for new landfills (Goh, 2012).

The aim of this research is to provide background information on the construction waste problems in Selangor and propose a practical method on how to manage and reduce construction waste. In order to achieve the aim, the objectives are generated and listed in the following:

i. To identify the quantification of construction waste being produced during construction.

ii. To identify the types of construction waste.

iii. To identify the approaches for the construction waste reduction. 
PLANNING MALAYSIA

Journal of the Malaysia Institute of Planners (2018)

\section{LITERATURE REVIEW}

Construction and demolition project generate a lot of waste material. The waste substance include disposed rubbish and unnecessary material but also contain excavated materials such as rock and soil, construction material such as bricks, premixed concrete, timber and steel. Tons of concrete waste in Selangor can be found from the demolition of old structure, concrete waste retrieved after refurbishment of structural, building construction by-products and the scrapped waste from the road pavement. However, the use of crushed concrete debris as a substitute to fine aggregate to mortar mix is discovered (Ganuron Jr., 2015).

Timber is an excellent building material and its suitability is seen when the material is used for heavy construction, such as heavy duty columns, door and window frames, sills and wooden beams. Rebar is a common steel bar that is hot rolled and is commonly used as a tensioning device to reinforce concrete and other masonry structures to help hold the concrete in a compressed state (HarrisSupplySolution.com, n.d.).

Meanwhile, the waste of bricks might cause by the factors of such as: lack of supervision when unloading of bricks at site, poor handling issues and also induced during delivery process. The scrapped of pipes and wire are generated during the plumbing and mechanical process of work. The waste of pipes and wire are usually due to poor plumbing and electrical service design, poor planning of materials disposal at site and also due to design variation issues which caused the frequent changing of pipes and wires (Formoso, Soibelman, De Cesare, \& Isatto, 2002).

However, Malaysia is yet to have the benchmarked waste generation rate in construction industry. By adopting the quantification of waste index formulated by Professor Chin Sun Poon for Hong Kong's construction project waste, the data of waste generated rate can be used for the comparison between Hong Kong and Malaysia. Hong Kong benchmarked waste generation rate comprises $0.175 \mathrm{~m}^{3} / \mathrm{m}^{2}$ for public residential, $0.250 \mathrm{~m}^{3} / \mathrm{m}^{2}$ for private residential and $0.200 \mathrm{~m}^{3} / \mathrm{m}^{2}$ for commercial (Poon, $\mathrm{Yu}, \& \mathrm{Ng}, 2001$ ).

Construction waste should not directly be disposed but it needs to pass through several processes before being disposed. The waste management hierarchy is a guide that is accepted for prioritising waste management practices with the goal of achieving friendly environmental effect. It sets out the preferred order of waste management practices (Zero Waste SA, 2012). The waste management hierarchy suggests that waste should be reduced, reused, recycled, recover then be disposed to proper dumpsite like landfill.

The good practice of waste classification avoid the direct disposal of hazardous substances into the landfill. The practise of onsite sorting out of waste should be initiated by every contractor in the construction sector. The contractor ought to train his employees to make the classification of material based on predefined waste hierarchy. The construction waste not only can be resell for 
reusable but can help contractor save for the transportation cost of carrying the waste to the landfill.

At the end of the waste management hierarchy, the construction waste that is transported to the legal landfill without special haulers permit are required (Illinois EPA, 2015). The amount of disposal waste can be minimized through the enactment of construction waste disposal charging scheme which has been implemented in Hong Kong. The objective of the scheme is to issue the charges to waste producers based on the waste they produced. The enforcement imposes the contractor to reuse, recover and recycle wastes in order to reduce the bill of disposal waste (Lu \& Tam, 2013).

The site waste management provides a principal which helps the contractors to estimate and record the amount and type of construction waste generated including the building up of the proper management actions for minimizing the quantity of construction waste. A license is issued to Duty Care stakeholders to record their waste carriers and monitor their waste management and illegal dumping (Papargyrppoulou, Preece, Padfield, \& Abdullah 2011).

\section{RESEARCH METHODOLOGY}

Quantitative research involves collection of numerical data to understand a specific situation. The quantitative method that used in this research is the archival data in numerical based data collected through case study method from the target respondent. Data regarding the construction waste generated from a project is collected from the selected company. All the collected information from the survey were checked and verified for their correctness. The data is analyzed to obtain the major factors of the topic.

Quantification is used for collecting primary data of this survey. Quantification is carried out by collecting the data that is require to calculate the waste index from the construction company. The utilization of waste index is to investigate the total amount of waste generated per Gross Floor Area. The parameter used to calculate waste index is stated in the following:

- $\mathrm{V}=$ truck volume (m3)

- $\mathrm{N}$ = total number of loads for waste proposal

Total waste generated by the project, $\mathrm{W}=\mathrm{V} \times \mathrm{N}$.

Thus, Waste index = W / GFA

\section{RESULT AND DISCUSSION}

The Zero Waste Index was presented as an alternative assessment tool for measuring the produced waste in this management system. The Zero Waste Index quantifies for energy, material and water conservation through recycling efforts rather than just simply measuring the waste diverted from landfills (Zaman, 2014). The nearer waste index to the zero value indicate the effectiveness and efficiency of the company in managing the construction waste on site. The results 
of the waste index retrieved from the quantification formulae are shown in Table 1. The data collected from the company includes gross floor area, truck volume, and total loads for waste quantification. The waste index in project $\mathrm{A}$ is $0.1508 \mathrm{~m}^{3} / \mathrm{m}^{2}$, project B is $0.2940 \mathrm{~m}^{3} / \mathrm{m}^{2}$, project $C$ is $0.0625 \mathrm{~m}^{3} / \mathrm{m}^{2}$ and project $\mathrm{D}$ is $0.1534 \mathrm{~m}^{3} / \mathrm{m}^{2}$ in respectively.

Table 1: Project data collected in Selangor area

\begin{tabular}{|c|c|c|c|c|}
\hline Project & $\mathrm{A}$ & $\mathrm{B}$ & $\mathrm{C}$ & $\mathrm{D}$ \\
\hline Contractor & $\mathrm{W}$ & $\mathrm{X}$ & $X$ & $\mathrm{Y}$ \\
\hline CIDB Grade & G7 & G7 & G7 & G7 \\
\hline $\begin{array}{l}\text { Type of } \\
\text { Building }\end{array}$ & $\begin{array}{c}\text { Mixed } \\
\text { Development: } \\
\text { Commercial \& } \\
\text { Residential } \\
\end{array}$ & $\begin{array}{l}\text { Commercial: } \\
\text { Building }\end{array}$ & $\begin{array}{c}\text { Single storey } \\
\text { Factory }\end{array}$ & $\begin{array}{l}\text { Commercial } \\
\text { Building }\end{array}$ \\
\hline Duration & $42 \mathrm{mth}$ & $15 \mathrm{mth}$ & $12 \mathrm{mth}$ & $36 \mathrm{mth}$ \\
\hline $\begin{array}{l}\text { Gross Floor } \\
\text { Area }(G F A)\end{array}$ & $135,962 \mathrm{~m}^{2}$ & $6250 \mathrm{~m}^{2}$ & $21,989 \mathrm{~m}^{2}$ & $62,288 \mathrm{~m}^{2}$ \\
\hline $\begin{array}{l}\text { Truck } \\
\text { Volume }(V) \\
\left(\mathrm{m}^{3}\right) \\
\end{array}$ & $16 \mathrm{~m}^{3}$ & $16 \mathrm{~m}^{3}$ & $16 \mathrm{~m}^{3}$ & $16 \mathrm{~m}^{3}$ \\
\hline $\begin{array}{l}\text { Total loads } \\
\text { for waste } \\
\text { proposal }(N)\end{array}$ & 1283 loads & 121 loads & 90 loads & 552 loads \\
\hline $\begin{array}{l}\text { Calculation } \\
\text { for Waste } \\
\text { Index }(C)\end{array}$ & $\begin{array}{c}(16 * 1283) / \\
135,962 \\
=0.1508\end{array}$ & $\begin{array}{c}(16 * 121) / \\
6,250 \\
=0.2940 \\
\end{array}$ & $\begin{array}{c}(16 * 90) / \\
21,989 \\
=0.0625 \\
\end{array}$ & $\begin{array}{c}(16 * 552) / \\
62,288 \\
=0.1534 \\
\end{array}$ \\
\hline $\begin{array}{l}\text { Waste Index } \\
(C)\left(\mathrm{m}^{3} / \mathrm{m}^{2}\right)\end{array}$ & 0.1508 & 0.2940 & 0.0625 & 0.1534 \\
\hline $\begin{array}{l}\text { Waste } \\
\text { Management }\end{array}$ & $\begin{array}{l}\text { Rebars and } \\
\text { metals are } \\
\text { reused and } \\
\text { salvaged. } \\
\text { System } \\
\text { formwork } \\
\text { being used to } \\
\text { reduce timber } \\
\text { waste. } \\
\text { Majority of the } \\
\text { waste manage } \\
\text { by MPKj. }\end{array}$ & $\begin{array}{l}\text { Rebars and } \\
\text { metals are } \\
\text { reused and } \\
\text { salvaged. } \\
\text { System } \\
\text { formwork } \\
\text { being used to } \\
\text { reduce timber } \\
\text { waste. } \\
\text { Majority of the } \\
\text { waste manage } \\
\text { by MPKj. } \\
\end{array}$ & $\begin{array}{l}\text { Rebars and } \\
\text { metals are } \\
\text { reused and } \\
\text { salvaged. } \\
\text { Majority of the } \\
\text { waste manage } \\
\text { by MBPJ. }\end{array}$ & $\begin{array}{l}\text { Rebars and } \\
\text { metals are } \\
\text { reused and } \\
\text { salvaged. } \\
\text { System } \\
\text { formwork } \\
\text { being used to } \\
\text { reduce timber } \\
\text { waste. } \\
\text { Majority of the } \\
\text { waste manage } \\
\text { by MPKj. }\end{array}$ \\
\hline
\end{tabular}

In addition, the data of the waste index was supported by the secondary data of the sources of waste. The secondary data was used as an evidence to prove the accuracy of the data obtained. The name of company and project were not revealed due to the protection of the companies' privacy but the sources of waste 
Khor Soo Cheen, Lim Chin-Yieh, Tan Seong Yeow, Olanrewaju A.A, Nik Nurul-Hidayah N.Y Wai Soon Han, \& Mohaad N.Y A Study of Construction Waste Practice in Selangor

and the major material is stated in the table. The table of sources of waste is shown in Table 2.

Table 2: Sources of waste

\begin{tabular}{|c|c|c|}
\hline Project & Sources of Waste & Major Material(s) \\
\hline A & $\begin{array}{l}\text { 1) Skim coat too thick. } \\
\text { 2) Overcast bored pile requires hacking } \\
\text { of concrete and cutting the steel bar } \\
\text { 3) Hacking due to design change } \\
\text { 4) Lapping length of cantilever beam too } \\
\text { long (design issue) }\end{array}$ & $\begin{array}{l}\text { Concrete, Rebar, Timber, } \\
\text { Tiles, Plaster, Bricks. }\end{array}$ \\
\hline $\mathrm{B}$ & $\begin{array}{l}\text { 1) Change of trenches depth (design } \\
\text { issue) } \\
\text { 2) Hacking of beam due to alignment } \\
\text { issue }\end{array}$ & Concrete, Rebar, Timber. \\
\hline $\mathrm{C}$ & $\begin{array}{l}\text { 1) Change of design (Steel Roof) } \\
\text { 2) Head of precast rc pile need to be cut } \\
\text { off due to ground condition (pile } \\
\text { setting length) }\end{array}$ & $\begin{array}{l}\text { Steel member, Concrete, } \\
\text { Rebar. }\end{array}$ \\
\hline $\mathrm{D}$ & $\begin{array}{l}\text { 1) Overcast bored pile requires hacking } \\
\text { of concrete and cutting the steel bar } \\
\text { 2) Lapping length of column starter bar } \\
\text { too long } \\
\text { 3) Hacking of concrete slab due to water } \\
\text { leakage issue (poor workmanship) }\end{array}$ & $\begin{array}{l}\text { Concrete, Rebar, Timber, } \\
\text { Tiles, Plaster, Bricks. }\end{array}$ \\
\hline
\end{tabular}

The waste index of Project B was the highest among the projects which was $0.2940 \mathrm{~m}^{3} / \mathrm{m}^{2}$ and went beyond the benchmarked standard norm of Hong Kong commercial project. The project involved activity of construction, demolition and refurbishment. In the job of refurbishment, the old design had to be demolished hence produced a large amount of construction waste. The waste produced after the demolition had to be placed temporarily at the waste storage and would be disposed by Kajang City Council in routine occasion. The stability of the building would be affected and caused plenty of changes in the building structural design.

Project $\mathrm{C}$ had the lowest waste index which was $0.0625 \mathrm{~m}^{3} / \mathrm{m}^{2}$ and was far lower than the benchmarked rate of Hong Kong because the project was a single storey factory. Although the gross floor area of the project was not the smallest, but the number of storey height was the least compared to other four projects. The concrete and rebar became major waste produced in Project $\mathrm{C}$ after the cut off head of precast reinforced Concrete (R.C) pile due to the ground condition. In addition, the change of the roof design required the substitution of 
PLANNING MALAYSIA

Journal of the Malaysia Institute of Planners (2018)

the obsolescence steel roof that involved the removal and rework activities which inevitably caused the huge amount of generated scrapped steel.

The final two projects (Project A and Project D) had the appropriate same waste index value which were $0.1508 \mathrm{~m}^{3} / \mathrm{m}^{2}$ and $0.1534 \mathrm{~m}^{3} / \mathrm{m}^{2}$ in respectively. The comparison of benchmarked waste generation rate should take the middle result in between private residential and commercial because of project A was a mixed development and thus the reference value should be $0.225 \mathrm{~m}^{3} / \mathrm{m}^{2}$. However, the result was far lower than the benchmarked rate. The waste produced in Project A mainly caused by the human errors in the construction stage. Hence, the client required for changing in design hence led to the production of construction waste due to the hacking down of the structure for rebuilding. Lastly, the waste index of Project D was considered good and acceptable when compared with the benchmarked rate. The outstanding circumstance in Project D happened during quality inspection. Project D encountered the factor of the water leakage problem that might be caused by the poor workmanship. The negligence in supervising the construction of plumber in the installation of pipework plus the faulty skills of the plumber had magnified the water leakage problem. Hence, the hacking of concrete slab is needed in order to fix the problem of water leakage in piping system.

\section{CONCLUSION}

The findings of the study have answered all of the objectives in this research. The objectives of the research are achievable through the case study survey method. Notwithstanding, the archival data provided by the respondents are sufficient to support the objectives of the research. The quantification of waste index shows the effort level of each company to manage the construction waste being produced. The second objective is achieved through the literature review of this research and through the data provided by the respondents in the case study. The major types of the construction waste found in their projects are typically from the source of rebar, concrete, bricks and tiles.

The third objective represented in Table 1 stated the waste management approaches of the companies for the construction waste reduction. All the statement are retrieved from quoting the justification given by respective interviewee of the company. The projects stakeholders prefer to use the system formwork instead of using timber formwork in order to reduce the timber wastage to enable the repetitive use of system formwork. The waste of rebars and steel members are thus salvaged or resold to the recycle market. Last but not least, the fact that the company obtained waste index was nearly to zero is considered an optimum result after compared with the benchmarked waste index established in Hong Kong. 
Khor Soo Cheen, Lim Chin-Yieh, Tan Seong Yeow, Olanrewaju A.A, Nik Nurul-Hidayah N.Y Wai Soon Han, \& Mohaad N.Y A Study of Construction Waste Practice in Selangor

\section{REFERENCES}

Estimating Errors \& Cost Overruns (2016). Retrieved from http://buildingadvisor.com/estimatingerrors/

Forrmoso, C. T., Soibelman, L., De Cesare, C., \& Isatto, E. L. (2002). Material waste in building industry: Main causes and prevention. Journal of Construction Engineering and Management, 128(4), 317-325.

Ganuron Jr., T. U. (2015). Recycling concrete debris from construction and demolition waste. International Journal of Advanced Science and Technology, 77, 7-24.

Goh, P. L. (2012). Space running out for dumpsites. Selangor Times, Issue 118 [Online] Retrieved from http://www.selangortimes.com/index.php?section=insight\& permalink=20120203120054-space-running-out-for-dumpsites

HarrisSupplySolution.com (n.d.) Retrieved from http://www.harrissupplysolutions.com/steelrebar.html

Hashim, K., Rabe, N. S., Osman, M. M., \& Zahari, R. K. (2017). Solid waste management practice and environmental awareness level of postgraduate and undergraduate students: Case study of UTM. Advance Science Letters, 23(7), 6073-6077.

Hong Kong Environmental Protection Department [HK EPD] (2015). What is Construction Waste? [Online]. Retrieved from http://www.epd.gov.hk/epd/misc/cdm/introduction.htm

Illinois Environmental Protection Agency [EPA] (2015). Construction and demolition debris. Retrieved from http://www.epa.illinois.gov/topics/small-business/publications/constructiondebris/index

Lu, W. \& Tam, V. (2013). Construction waste management policies and their effectiveness in Hong Kong: A longitudinal review. The University of Hong Kong, Renewable \& Sustainable Energy Reviews, 23, 214-223.

Masudi, A. F., Che Hassan, C. R., Mahnood, N. Z., Mokhtar, S. N., \& Sulaiman, N. M. (2011) Construction waste quantification and benchmarking: A study in Klang Valley, Malaysia Journal of Chemistry and Chemical Engineering, 5(10), 909-916.

Mohd Din, S. A., Nik Yahya, N. N. H., \& Abdullah, A. (2013). Fine particulates matter (PM2.5) from coal-fired power plant in Manjung and its health impacts. Procedia - Social and Behavioral Sciences, 85, 92 - 99.

Papargyrppoulou, E., Preece, C., Padfield, R., \& Abdullah, A. A. (2011, June). Construction waste management in Malaysia: A contractor's perspective. Management and Innovation for a Sustainable Built Environment. June 20-23, 2011, Amsterdam, The Netherlands.

Poon, C. S., Yu, T. W., \& Ng, L. H. (2001). A guide for managing and minimizing building and demolition waste. Hong Kong: Dept. of Civil \& Structural Engineering, Hong Kong Polytechnic University.

Tey, J. S., Goh, K. C., Kek, S. L., \& Goh, H. H. (2016, December). Current practice of waste management system in Malaysia: Towards sustainable waste management. 1st FPTP Postgraduate Seminar: Towards Sustainable Management. December 23, 2013, Batu Pahat, Malaysia.

Zaman, A. U. (2014). Measuring waste management performance using the 'Zero Waste Index'. Journal of Cleaner Production, 66, 407-419.

Zero Waste SA (2012). Waste management hierarchy. Retrieved from http://www.zerowaste.sa.gov.au /about-us/waste-management-hierarchy 